FORUM

\title{
Bidimensional transfer of effects among organisms: An overlooked concept in community ecology
}

\author{
Transferencia bidimensional de efectos entre organismos: Un concepto desatendido \\ en ecología de comunidades
}

\author{
RODRIGO RAMOS-JILIBERTO ${ }^{1 *} \&$ ADRIANA ARÁNGUIZ-ACUÑA ${ }^{1}$
}

${ }^{1}$ Centro Nacional del Medio Ambiente, Universidad de Chile, Av. Larraín 9975 La Reina, Santiago, Chile

${ }^{*}$ Corresponding author: ramos.jiliberto@gmail.com

\begin{abstract}
Although geneticists and population ecologist have considered in their explanations the importance of both horizontal -interspecific- and vertical -intraspecific- paths for the flow of information, energy or matter among organisms, community ecology and particularly network ecology have been strongly biased towards considering only horizontal effects. In this article our aim is to put on view of ecologists the concepts of vertical and horizontal transfer of disturbance effects in communities, and discuss the relevance of the interplay between both processes for ecological research. We support that incorporating this view into community ecology could be a promising new research avenue, and may improve our understanding about the responses of communities to natural and anthropogenic disturbances.
\end{abstract}

Key words: ecological networks, ecological interactions, food webs, horizontal effects, vertical effects.

\section{RESUMEN}

Aunque genetistas y ecólogos de poblaciones han considerado en sus explicaciones la importancia de vías tanto horizontales -interespecíficas- como verticales -intraespecíficas- para el flujo de información, energía o materia entre organismos, la ecología de comunidades y particularmente la ecología de redes han estado fuertemente sesgadas hacia considerar solo efectos horizontales. En este artículo nuestro propósito es poner en vista de los ecólogos los conceptos de transferencia vertical y horizontal de efectos de perturbaciones en comunidades, así como discutir la relevancia de la interacción entre ambos procesos para la investigación ecológica. Sostenemos que la incorporación de esta perspectiva en ecología de comunidades podría constituir una línea de investigación promisoria y podría mejorar nuestro entendimiento acerca de las respuestas de las comunidades a perturbaciones antropogénicas y naturales.

Palabras clave: efectos verticales, efectos horizontales, interacciones ecológicas, redes ecológicas, redes tróficas.

\section{INTRODUCTION}

The development of genetic engineering has allowed geneticists identifying that horizontal gene transfer (i.e. without involving reproduction) among neighbor microorganisms occurs indeed more frequently that vertical (parental) transfer (McDaniel et al. 2010). Although in genetics the vertical intraspecific dimension of gene transfer has been the hegemonic paradigm, it is now recognized that horizontal transfer provides a rapid means of adaptation to environmental change and, unlike vertical transfer, often occurs among organisms of different species and indeed belonging to different kingdoms (Aoki \& Syõno 1999, Kondo et al. 2002, Brown 2003). Therefore, in genetics it is widely recognized the importance of both vertical -intraspecific- and horizontal -interspecific- transfer as major means of gene propagation and source of evolutionary novelty. In ecology, conversely, the transfer of effects among organisms has been thought to be mainly a horizontal process, among organism that interact sharing space and time.

More recently, population ecologists have incorporated the vertical transmission of effects (particularly maternal effects) and its interplay with horizontal transfer of effects (direct density dependence) in their theories 
for explaining the shape of population dynamics (Ginzburg \& Taneyhill 1994). Nevertheless, we stress that this has been not the case in community ecology. Furthermore, we guess that incorporating this view into community ecology could be a promising new research avenue, and may improve our understanding about the responses of communities to natural and anthropogenic disturbances.

Community ecology, and particularly its refreshed face of network ecology, emphasizes the structure of connections among the organisms or groups of organisms as determinant of the dynamics and robustness of communities to different kinds of disruption. In this view, form and function of ecological systems are tightly bound (see Gross \& Blasius 2008) and the collective behavior of communities has less to do than previously thought with the identity and functioning of their isolated parts. Nevertheless, the recent vigorous development of network ecology has been strongly biased towards considering only horizontal effects.

Our aim in this communication is to put on view of ecologists the concepts of vertical and horizontal transfer of disturbance effects in communities. We briefly discuss the relevance of the interplay between both processes for basic ecological research and its significance for environmental studies.

\section{EFFECTS}

Following the advances of statistical causal inference (Pearl 2009, ArunKumar and Venkatesan 2011), an effect can be defined as the capacity to transmit changes between variables. Thus, from an ecological point of view, an effect occurs whenever changes in an organism's trait as a response to an environmental stimulus, is transmitted to other organisms by mechanisms other than genetic inheritance. It is clear that, for such effect to occur from organism A to organism B, both $A$ and $B$ must be linked ecologically. More precisely, fitness of $B$ should depend on the state of a trait of A (e.g., size, physiological condition, etc.)

\section{Horizontal effects}

The study of interactions among organisms and populations has been a foundational issue in ecology. Pairwise interactions refer to a mutual influence between two entities, say $\mathrm{A}$ and $\mathrm{B}$, and can be decomposed into two directional effects: $\mathrm{A} \rightarrow \mathrm{B}$ and $\mathrm{B} \rightarrow \mathrm{A}$. These effects can be direct, i.e. with no intermediaries, or indirect in which one or more entities mediate the effect. Net effects account for all possible direct and indirect effects of one entity on another one.

Ecological horizontal effects (Fig. 1) denote the direction and magnitude in which the presence of organisms of one type alters the fitness of the others. Assessing the sign and strength of effects is not an easy task (Wootton \& Emmerson 2005), especially if indirect effects are considered and the populations are not assumed to be in steady state (Abrams 2001). Nevertheless, valuable advances have been made in linking the distribution of interactions into ecological networks to their dynamics (McCann et al. 1998, Bascompte et al. 2003,

\section{Horizontal effects}

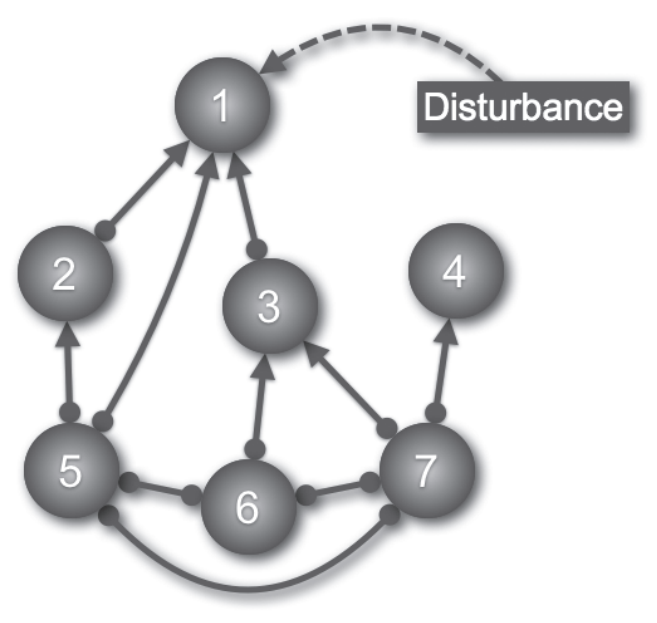

Fig. 1: Representation of horizontal effects. Nodes represent populations of different species related by interactions composed of positive (links ending in arrowheads) and negative (links ending in circles) effects. A disturbance exerted on species 1 can be transmitted via direct effects to species 2, 3 and 5; and via indirect effects to the rest of species in the community.

Representación de efectos horizontales. Los nodos representan poblaciones de diferentes especies relacionadas por interacciones compuestas de efectos positivos (enlaces terminados en punta de flecha) y negativos (enlaces terminados en círculo). Una perturbación ejercida sobre la especie 1 puede ser transmitida vía efectos directos a las especies 2 , 3 y 5 ; y vía efectos indirectos al resto de las especies de la comunidad. 
Olesen et al. 2007, Thebault \& Fontaine 2010). The importance of identifying the distribution and strength of interspecific interactions is that those properties are considered to determine the propagation of environmental disturbances over the community (Bascompte \& Stouffer 2009, González et al. 2011). A number of theoretical tools have been used for assessing the propagation and outcomes of disturbances in ecological networks. For example, a static approach (i.e. without population dynamics) has been used for studying the responses of communities to the loss of species (Dunne et al. 2003), by means of dynamic qualitative analyses it has been possible to study the consequences of pollution (Ramos-Jiliberto et al. 2012a) and through numerical simulation of dynamical models we have studied the expected consequences of removing exotic (Valdovinos et al. 2009) or native (RamosJiliberto et al. 2009) groups of species. In spite of the potential usefulness of these approaches, all of them disregard transgenerational effects of disturbances on demographic traits. We stress that adding this temporal (i.e. vertical) dimension to future models of interaction networks would represent a step forwards in the search of fundamental determinants of community dynamics and responses of ecosystems to environmental disturbances.

\section{Vertical effects}

Life history and demographic responses to environmental change can be transmitted "vertically", across successive generations (Fig. 2). These responses to stimuli perceived by parents but observed in the offspring are known as transgenerational effects. Maternal effects are a well-known kind of transgenerational effects, and they are defined as the causal influence of the parental genotype or phenotype on the offspring phenotype (Wolf $\&$ Wade 2009). These developmental changes incorporate phenotypic variation that cannot be justified by genetic variation (Uller 2008). The mechanism often implied in this process is the environment (in the broadest sense) provided to offspring by their parents. Transgenerational effects driven by natural or anthropogenic disturbances have been reported for many traits in many taxa, e.g. egg size of fish (Einum \& Flemming 1999), seed size, germination timing

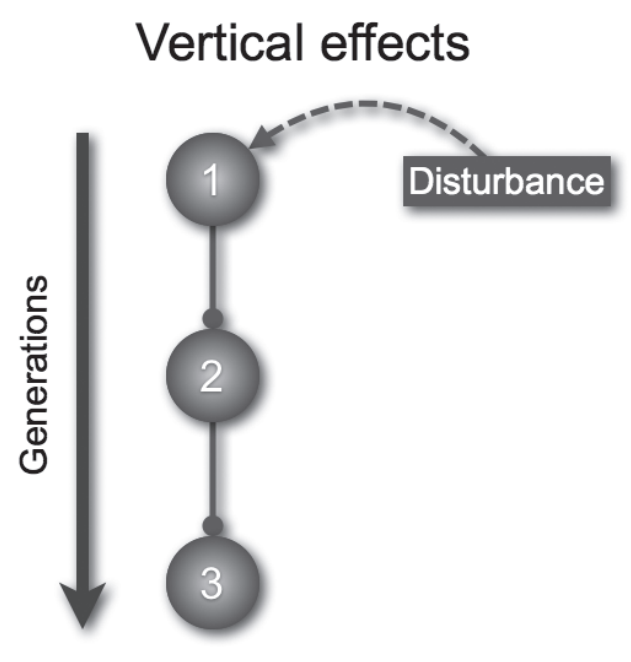

Fig. 2: Representation of vertical effects. Nodes represent the same population over successive generations (1 to 3). Organisms belonging to generation 1 receive the impact of an environmental disturbance, which affect organisms of the next generation, which also transmit the effect to generation 3. Links ending in circles represent negative effects, as an example.

Representación de efectos verticales. Los nodos representan la misma población a través de generaciones sucesivas (1 a 3). Organismos pertenecientes a la generación 1 reciben en impacto de una perturbación ambiental, la cual afecta a los organismos de la siguiente generación, la cual también transmite el efecto a la generación 3. Los enlaces terminados en círculo representan efectos negativos, a modo de ejemplo.

and success, leaf production, and early growth in plants (Schuler \& Orrock 2012), life-history shifts in Daphnia (Carvajal-Salamanca et al. 2008), increased metabolic rate in Daphnia (Fernández-González et al. 2011), immune defenses to copper in blow fly (Pölkki et al. 2012). Thus, vertical -transgenerational- effects lead to the transmission of changes in parents' traits driven by an environmental stimulus to changes in offspring's traits when the latter may not be yet subjected to the stimulus. This constitutes a source of delayed life-history and demographic effects (Beckerman et al. 2002). Vertical effects and specifically parental effects -either adaptive or not- have been show to influence the dynamics of populations, explaining oscillatory behavior better than other hypothesized alternative mechanisms (Kendall et al. 2005, see also Inchausti \& Ginzburg 2009). Population trajectories could show cycles due to density-dependent lags 
promoted by maternal effects (Benton et al. 2001, 2005, Beckerman et al. 2002). Although there is evidence that maternal effects may indirectly affect growth rates by changing the competitive environment of offspring (Benton et al. 2005), this way of thinking that is well considered in genetics and population ecology has not been adequately transferred to the study of ecological interactions as determinants of the structure and dynamics of ecological communities.

\section{THINKING BIDIMENSIONAL}

Given the occurrence of both horizontal and vertical transfer, the likelihood of finding a bidimensional transfer of ecological effects arises as a logical consequence. This could occur, for example, since a horizontally transmitted change could be a result of a change that was promoted vertically on the emitter. i.e. the horizontal emitter could have been a vertical receptor (Fig. 3). Conversely, the emitter of a vertical effect could also be a previous receptor of a horizontal effect. To our knowledge, there is no empirical demonstration of this kind of complex effect in real communities, but we suspect that indeed there has not been a serious intent to find it.

The ecological significance of this bidimensional transfer of effects, in the case that their occurrence in nature were demonstrated, is not minor. First, it represents an unexplored path of propagation of disturbances, and therefore it is intricately linked with the stability properties of communities. Second, it represents a source of complexity in ecological networks, whose potential impact on community dynamics should be elucidated by assessing patterns of occurrence, distribution over the network structure, characteristic diameter of influence and timescales in which they act. Third, this kind of effects could challenge our ability to predict community responses to natural or anthropogenic disturbances. Last, bidimensional effects should explain delayed and far-acting effects of pollutants and other environmental disturbances on complex communities. Overall, we guess that bidimensional effect are likely to occur in nature, and its discovery should promote opening a new research agenda with

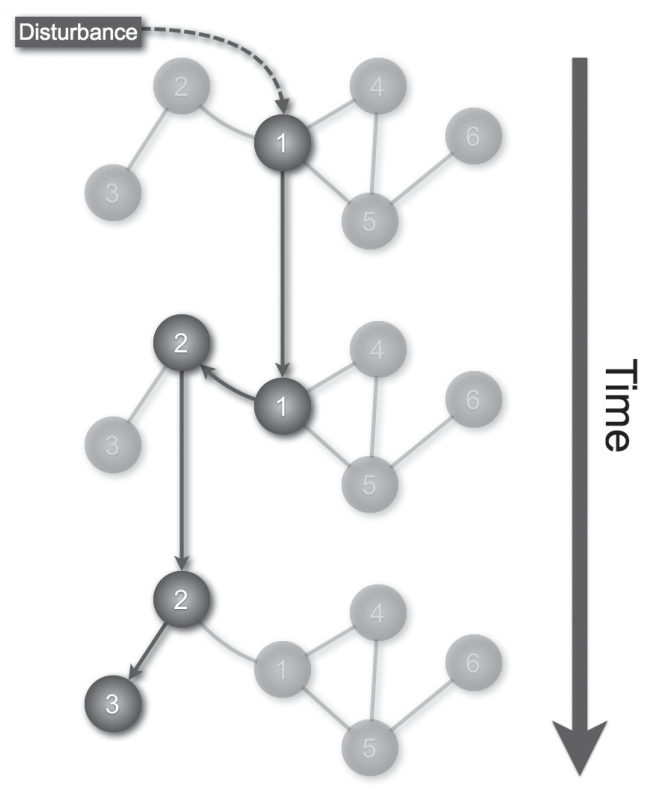

Fig. 3: Representation of horizontal and vertical transfer of effects within an ecological community. Nodes are populations linked by ecological interactions (among nodes with different labels) and parental relationships (among nodes with the same label). The populations and interactions that do not participate in the route of effects of this example are shown in light tones. Population1 is being affected by an environmental disturbance, but its effects are transmitted vertically and they are only expressed in the next generation. Next, the changes in demographic traits of population 1 are transmitted horizontally to population 2, which also transmit the effect vertically to the next generation. At the final time frame, the effect received vertically by 2 is transferred horizontally to population 3 .

Representación de efectos horizontales y verticales dentro de una comunidad ecológica. Los nodos son poblaciones vinculadas por interacciones ecológicas (entre nodos con diferente etiqueta) y relaciones parentales (entre nodos con igual etiqueta). En tonos suaves se muestran las poblaciones e interacciones que no participan en la ruta de efectos de este ejemplo. Población 1 está siendo afectada por una perturbación ambiental, pero sus efectos se transmiten verticalmente y se expresan solo en la generación siguiente. Después, los cambios en rasgos demográficos de la población 1 se transmiten horizontalmente a la población 2 , la cual también transmite el efecto verticalmente a la siguiente generación. Al final del marco de tiempo, el efecto recibido verticalmente por 2 es transmitido horizontalmente a la población 3 .

interesting implications for both basic and applied ecological research.

Some interesting patterns are expected to emerge using this approach. Bidimensional transfer could extend the timescale in which indirect ecological effects take place. By 
adding delays in the interspecific interactions, the vertical dimension may alter the stability properties of the networks and thus their patterns of responses to environmental perturbations. In addition, adding the vertical dimension to ecological dynamics translates to short-time inheritance of trait values, which could lead to loss of stability. In sum, we expect the relationship between (horizontal) network structure and network dynamics being modulated by the vertical structure.

Nevertheless, things are not so simple. Both taxonomic and temporal resolution of networks is highly relevant for detecting bidimensional effects. The taxonomic aggregation in the building of ecological networks, although unavoidable to a certain degree, has been recognized to alter the (horizontal) structure and therefore the prediction of the functioning of networks (Abarca-Arenas \& Ulanowicz 2002, Jordan 2003, Thompson et al. 2012). This should be also true for the vertical structure, since transgenerational links in a functional group could belong to a variable and undefined number of species within the group. On the other hand, temporal resolution of horizontal effects has been addressed since years (Menge 1997), but it is crucial to consider them in the context of bidimensional effects. Too broad temporal grain will collapse many generations of some organisms, thus yielding a picture not much different from the usual static (horizontal) approach. In turn, too high temporal resolution could loss the signal of the longer-lived species. Thus, the network resolution in terms of topology, time scale and spatial scale of research should be carefully chosen according to the biology of the species at hand.

Moreover, identical environmental perturbations applied to populations with different age or size structures will lead to different population responses, since we could expect that the effects will be propagated differently both vertically and horizontally. Interspecific interactions are not fixed but vary over time. On the one hand, interaction strengths are dynamic (Abrams 2001). This implies that the magnitude and scope of bidimensional effects should also be highly variable. On the other hand, some interactions among species appear and disappear through time in response to environment stimuli, typically the trophic environment of the organisms (Beckerman et al. 2006, Petchey et al. 2008). The network consequences of this flexibility or plasticity of interactions are under study presently (Kaiser-Bunbury et al. 2010, Thierry et al. 2011, Ramos-Jiliberto et al. 2012b), but considering that such plastic interactions could participate in bidimensional paths of effects adds a level of complexity that makes the study of the structure/ dynamics interplay in ecological networks more challenging and stimulating.

ACKNOWLEDGEMENTS: This study was supported by grants FONDECYT 1120958 to RR-J and 3110176 to AA-A.

\section{LITERATURE CITED}

ABARCA-ARENAS LG \& RE ULANOWICZ (2002) The effects of taxonomic aggregation on network analysis. Ecological Modelling 149: 285-286.

ABRAMS PA (2001) Describing and quantifying interspecific interactions: a commentary on recent approaches. Oikos 94: 209-218.

AOKI S \& K SYÕNO (1999) Horizontal gene transfer and mutation: Ngrol genes in the genome of Nicotiana glauca. Proceedings of the National Academy of Sciences USA 96: 13229-13234

ARUNKUMAR N \& P VENKATESAN (2011) Recent advancement in causal inference. International Journal of Pharmaceutical Studies and Research 2: $10-19$.

BASCOMPTE J \& DB STOUFFER (2009) The assembly and disassembly of ecological networks. Philosophical Transactions of the Royal Society B 364: 1781-1787.

BASCOMPTE J, P JORDANO, CJ MELIÁN \& JM OLESEN (2003) The nested assembly of plantanimal mutualistic networks. Proceedings of the National Academy of Sciences USA 100: 93839387.

BECKERMAN A, OL PETCHEY \& PH WARREN (2006) Foraging biology predicts food web complexity. Proceedings of the National Academy of Sciences USA 103: 13745-13749.

BECKERMAN A, TG BENTON, E RANTA, V KAITALA \& P LUNDBERG (2002) Population dynamic consequences of delayed life-history effects. Trends in Ecology and Evolution 17: 263-269.

BENTON TG, E RANTA, V KAITALA \& AP BECKERMAN (2001) Maternal effects and the stability of population dynamics in noisy environments. Journal of Animal Ecology 70: 590599.

BENTON TG, SJ PLAISTOW, AP BECKERMAN, CT LAPSLEY \& S LITTLEJOHNS (2005) Changes in maternal investment in eggs can affect population dynamics. Proceedings of the Royal Society B 272: $1351-1356$

BROWN JR (2003) Ancient horizontal gene transfer. Nature Reviews Genetics 4: 121-132.

CARVAJAL-SALAMANCA JL, A ARÁNGUIZ-ACUÑA, R RAMOS-JILIBERTO \& L ZÚÑIGA (2008) Immediate and delayed life-history responses of 
Daphnia ambigua to conspecific cues. Journal of Plankton Research 30: 1117-1122.

DUNNE JA, J HARTE \& KJ TAYLOR (2003) Subalpine meadow flowering phenology responses to climate change: integrating experimental and gradient methods. Ecological Monographs 73: 69-86.

EINUM S \& IA FLEMING (1999) Maternal effects of egg size in brown trout (Salmo trutta): norms of reaction to environmental quality. Proceedings of the Royal Society B 266: 2095-2100.

FERNANDEZ-GONZALEZ MA，J GONZALEZBARRIENTOS, MJ CARTER \& R RAMOSJILIBERTO (2011) Parent-to-offspring transfer of sublethal effects of copper exposure: metabolic rate and life-history traits of Daphnia. Revista Chilena de Historia Natural 84: 195-201.

GINZBURG LR \& DE TANEYHILL (1994) Population cycles of forest lepidoptera: a maternal effect hypothesis. Journal of Animal Ecology 63: 79-92.

GONZALEZ A, B RAYFIELD \& Z LINDO (2011) The disentangled bank: How loss of habitat fragments and disassembles ecological networks. American Journal of Botany 98: 503-516.

GROSS T \& B BLASIUS (2008) Adaptive coevolutionary networks: a review. Journal of the Royal Society Interface 5: 259-271.

INCHAUSTI P \& LR GINZBURG (2009) Maternal effects mechanism of population cycling: a formidable competitor to the traditional predator -prey view. Philosophical Transactions of the Royal Society B 364: 1117-1124.

JORDAN F (2003) Comparability: the key to the applicability of food web research. Applied Ecology and Environmental Research 1: 1-18.

KAISER-BUNBURY CN, S MUFF, J MEMMOTT, CB MÜLLER \& A CAFLISCH (2010) The robustness of pollination networks to the loss of species and interactions: a quantitative approach incorporating pollinator behaviour. Ecology Letters 13: 442-452.

KENDALL BE, SP ELLNER, E MCCAULEY, SN WOOD, CJ BRIGGS, WW MURDOCH \& P TURCHIN (2005) Population cycles in the pine looper moth: dynamical tests of mechanistic hypotheses. Ecological Monographs 75: 259-276.

KONDO N, N NIKOH, N IJICHI, M SHIMADA \& $T$ FUKATSU (2002) Genome fragment of Wolbachia endosymbiont transferred to $\mathrm{X}$ chromosome of host insect. Proceedings of the National Academy of Sciences USA 99: 14280-14285.

McCANN K, A HASTINGS \& GR HUXEL (1998) Weak trophic interactions and the balance of nature. Nature 395: 794-798.

McDANIEL LD, E YOUNG, J DELANEY, F RUHNAU, KB RITCHIE \& JH PAUL (2010) High frequency of horizontal gene transfer in the oceans. Science 330: 50 .

MENGE BA (1997) Detection of direct versus indirect effects: were experiments long enough? The American Naturalist 149: 801-823.

OLESEN JM, J BASCOMPTE, YL DUPONT \& P JORDANO (2007) The modularity of pollination networks. Proceedings of the National Academy of Sciences USA 104: 19891-19896.

PEARL J (2009) Causal inference in statistics: An overview. Statistics Surveys 3: 96-146.

PETCHEY OL, AP BECKERMAN, JO RIEDE \& PH WARREN (2008) Size, foraging, and food web structure. Proceedings of the National Academy of Sciences USA 105: 4191-4196.

PÖLKKI M, K KANGASSALO \& MJ RANTALA (2012) Transgenerational Effects of Heavy Metal Pollution on Immune Defense of the Blow Fly Protophormia terraenovae. PLos One 7: e38832.

RAMOS-JILIBERTO R, L GARAY-NARVAEZ \& MH MEDINA (2012a) Retrospective qualitative analysis of ecological networks under environmental perturbation: a copperpolluted intertidal community as a case study. Ecotoxicology 21: 234-43.

RAMOS-JILIBERTO R, FS VALDOVINOS, P MOISSET DE ESPANÉS \& JD FLORES (2012b) Topological plasticity increases robustness of mutualistic networks. Journal of Animal Ecology 81: 896-904.

RAMOS-JILIBERTO R, AA ALBORNOZ, FS VALDOVINOS, C SMITH-RAMÍREZ, M ARIM, JJ ARMESTO \& PA MARQUET (2009) A network analysis of plant-pollinator interactions in temperate rain forests of Chiloé Island, Chile. Oecologia 160: 697-706.

SCHULER MS \& JL ORROCK (2012) The maladaptive significance of maternal effects for plants in anthropogenically modified environments. Evolutionary Ecology 26: 475-481.

THEBAULT E \& C FONTAINE (2010) Stability of ecological communities and the architecture of mutualistic and trophic networks. Science 329: 853-856.

THIERRY A, AP BECKERMAN, PH WARREN, RJ WILLIAMS, AJ COLE \& OL PETCHEY (2011) Adaptive foraging and the rewiring of sizestructured food webs following extinctions. Basic and Applied Ecology 12: 562-570.

THOMPSON RM, JA DUNNE \& G WOODWARD (2012) Freshwater food webs: towards a more fundamental understanding of biodiversity and community dynamics. Freshwater Biology 57: 1329-1341.

ULLER T (2008) Developmental plasticity and the evolution of parental effects. Trends in Ecology and Evolution 23:432-438.

VALDOVINOS FS, R RAMOS-JILIBERTO, JD FLORES, C ESPINOZA \& G LOPEZ (2009) Structure and dynamics of pollination networks: the role of alien plants. Oikos 118: 1190-1200.

WOLF J \& MJ WADE. (2009) What are maternal effects (and what are they not)? Philosophical Transactions of the Royal Society B 364: 11071115.

WOOTTON JT \& M EMMERSSON (2005) Measurement of interaction strength in nature. Annual Review of Ecology, Evolution and Systematics 36: 419-44. 